\title{
Human chorionic gonadotropin decreases the phosphorylated tau protein level in streptozotocin-Alzheimeric male rats' hippocampus
}

\author{
Gozal Bahlakeh ${ }^{1}$, Mehrdad Jahanshahi², Mohsen Saeidi ${ }^{3}$ \\ ${ }^{1}$ Student Research Committee, Neuroscience Research Center, Golestan University of Medical Sciences, Gorgan, Iran, ${ }^{2}$ Neuroscience \\ Research Center, Golestan University of Medical Sciences, Gorgan, Iran, ${ }^{3}$ Stem Cell Research Center, Golestan University of Medical \\ Sciences, Gorgan, Iran
}

\begin{abstract}
Introduction: The pharmacological suppression of luteinising hormone or human chorionic gonadotropin (hCG) can reduce $A \beta$ plaques in the brains of rats and mice, but the effects of $h C G$ on the phosphorylated tau protein level in the hippocampus have not been studied. Therefore, we investigated the effects of hCG on the phosphorylated tau protein level and its effect on $h C G$ receptor-immunoreactive neuron density in the hippocampus of Alzheimer's disease (AD) model rats (streptozotocin [STZ] injected intracerebroventricularly).

Material and methods: The rats were administered hCG (50,100, and $200 \mathrm{IU} / 200 \mu \mathrm{l}$ saline, intraperitoneally) or vehicle once/day for three days after injection of STZ. The passive avoidance memory test was performed 6 hours after the last hCG injection. The phosphorylated tau protein level in the hippocampus was measured by ELISA, and hCG receptor-immunoreactive neurons were shown by immunohistochemical technique in areas of hippocampus.

Results: Treatment with hCG attenuated memory deficiencies and reduced the level of phosphorylated tau protein in the hippocampus. $h C G$ also improved the density of $h C G$ receptor-immunoreactive neurons. The high dose of $h C G$ hormone (200 IU/200 $\mu \mathrm{l}$ saline) seemed to have a significant effect on passive avoidance memory, phosphorylated tau protein concentration, and accumulation of hCG receptor-immunoreactive neurons in Alzheimeric rats' hippocampus. Conclusions: In conclusion, hCG can provide protection against memory deficits induced by STZ and it can inhibit accumulation of tau hyperphosphorylation in the hippocampus. Furthermore, $h C G$ can increase the $h C G$ receptor-ir neurons number in the rats hippocampus after ICV injection of STZ.
\end{abstract}

Key words: $h C G$, streptozotocin, passive avoidance memory, phosphorylated tau protein, $h C G$ receptor, hippocampus.

\section{Introduction}

Alzheimer's disease (AD) is the most widespread type of dementia in the world, and an estimated
5.4 million Americans of all ages had AD in 2016 [7]. Alzheimer's disease, which has been considered as a neurodegenerative disorder, affects disproportionately individuals over 65 years old. Epidemiological

\section{Communicating author}

Dr. Mehrdad Jahanshahi, Department of Anatomy, Neuroscience Research Centre, Faculty of Medicine, Gorgan University of Medical Sciences, km 4 Gorgan-Sari road (Shastcola), Gorgan, Iran, phone: 0098-17-32420515, fax: 0098-17-32420515, e-mail: mejahanshahi@yahoo.com 
data show that $A D$ affects $11 \%$ of persons above 65 years of age and one-third of people over the age of 85 years (32\%) [33]. In the developed world, AD is considered to be the sixth principal cause of death although estimates involving death from related health issues reflect the risk even greater $[5,6]$. Alzheimer's disease is pathologically characterised by the presence of intracellular hyper-phosphorylated neurofibrillary tau tangles (NFTs), extracellular deposits of plaques of amyloid $\beta(A \beta)$, and neuronal cell death $[49,50]$.

Tau protein belongs to the group of microtubule-associated proteins (MAPs) [36]; it is a neuronal protein that is phosphorylated in its proline-rich region. In fact, phosphorylation facilitates accumulation of tau in the formation of paired helical filaments (PHFs). Between the kinases known to phosphorylate tau, GSK3 plays a key main role [9]. Physiologically, tau plays an important role in microtubule stabilisation (tau has a vital role in stabilisation of microtubules), neurite outgrowth, and axonal transportation [66]. Tau is the main component of the PHFs that make up the NFTs, and it is abnormally phosphorylated in PHFs and NFTs [35]. In pathological conditions, such as AD, not only does abnormal phosphorylation of tau protein reduce its tubulin binding capacity leading to microtubule disorganisation, but also this protein self-polymerises and combines in the form of NFTs [36]. Furthermore, tau phosphorylation, which leads to tau dysfunction, results in declined cell viability. Actually, in neurodegenerative diseases in which tau pathology has been observed, the phosphorylation of tau is abnormal [35]. The spatiotemporal progression of tau combinations from the hippocampus and entorhinal cortex to cortical areas $[18,28]$ has been shown to be related with cognitive deficits [30,32], supporting a critical role of tau pathology in AD-related memory deficiencies [37].

Human chorionic gonadotropin ( $\mathrm{hCG}$ ) is a heterodimeric glycoprotein hormone that is structurally and functionally similar to luteinising hormone (LH) [47]. Human chorionic gonadotropin has the ability to cross the BBB (blood-brain barrier), and its receptors are expressed by neurons in the brain [12]. While oestrogen is recognised as an important modulator of mood, anxiety, and memory, the roles of the gonadotropin hormones, LH, and hCG in the regulation of memory and behaviour are unclear. Most research on the effect of gonadotropin hormones on behaviour have focused on the role of hCG in the modulation of behaviours experienced during pregnancy including nausea and vomiting, appetite, revulsion to food and smells, nervousness, anxiety, insomnia, and cognitive deficits including memory impairment $[19,55]$. In culture systems, hCG has been reported to support the survival and neurite outgrowth in primary neurons, and it induced differentiation of PC12 cells, probably through activation of LH/CG-R (LH/choriogonadotropin receptor) [3,47]. hCG treatment enhanced recovery of motor function in rats with complete spinal cord transection. These outcomes suggest a potential role for hCG/ $\mathrm{LH}$ and LH/CG-R in the development and maturation of the mammalian nervous system [47]. However, recent associations between elevated $\mathrm{LH}$ levels and increased risk of $A D$ have caused a re-evaluation of the role of the gonadotropin hormones in the modulation of neuropathology, AD-related behaviour, and memory $[15,16,58,61]$.

Both hCG and LH hormones bind to the same LH/hCG receptor [53] and signal through a common G-protein-coupled receptor [46]. hCG has more potential than LH due to its higher receptor binding affinity and a longer circulatory half-life [53]. Although LH/hCG receptor has been thought to be limited to gonads, evidence shows its expression in non-gonadal tissue such as the CNS $[3,4,21]$. The presence of $\mathrm{LH} / \mathrm{hCG}$ receptors was proven in the median preoptic area of hypothalamus, hippocampus, amygdala, cerebellum, cerebral cortex, and brain stem of the rat, with high density in hypothalamus and hippocampus [39]. Both neurons and glial cells were shown to express LH/hCG receptor $[3,4,65]$. The $L H / h C G$ receptor may be involved in the development and differentiation of neurons, sleepwake activity, and the controlling feedback mechanism of gonadotropin-releasing hormone and $\mathrm{LH}$ synthesis in the hypothalamus and pituitary gland, respectively $[38,44,45,59]$.

Association of LH and $\mathrm{hCG}$ in AD progress was discussed [54]. For example, if the LH level is reduce, it can decreases $A b$ levels in mouse brain and can prevent memory loss in neurotoxin-induced $A D$ model. High levels of LH or direct exposure to LH can increase Ab levels. Also, LH endorses amyloidogenic pathway of metabolism of amyloid precursor protein, secretion of $A b$, and its deposition in the aged brain. Administration of hCG leads to an accumulation of Ab40, soluble Ab1-40 and Ab1-42 levels, and 
cognitive deficits, as well as an increase in activity of b-secretase in a dose-dependent manner. Ablation of $\mathrm{LH}$ activities through suppression of $\mathrm{LH} / \mathrm{hCG}$ receptor gene leads to a reduction $A b$ accumulation, plaque formation, and progress in neuropathological features in a mouse model of APPSW+/LHr.

Previous studies have shown that $\mathrm{LH} / \mathrm{hCG}$ administration increased $\mathrm{Ab}$ accumulation in rat and mouse brains $[14,17,25]$, but the effects of hCG on phosphorylated tau protein level in the hippocampus have not been studied. Hence, we investigated the effects of hCG on learning and memory impairments after ICV injection of streptozotocin (STZ) in rats. We also examined its effect on hCG receptor-immunoreactive (-ir) neuron density and phosphorylated tau protein level in the hippocampus of AD model rats.

\section{Material and methods}

\section{Animals}

Ten-week-old male Wistar rats with weighing 200 $\pm 20 \mathrm{~g}$ (Pasteur Institute, Tehran, Iran) were used. The animals were maintained at temperature of $22 \pm 3^{\circ} \mathrm{C}$ on a light/dark (12-hour) cycle, with access to food and water ad libitum. The animals were acclimatised for one week prior to any experimentation. The experimental protocol was checked and approved by the Committee of Ethics in Golestan University of Medical Sciences, Gorgan, Iran. All surgery was performed under anaesthesia, and all efforts were made to reduce animal suffering.

\section{Surgery and intracerebroventricular administration of streptozotocin}

For intracerebroventricular (ICV) administration of STZ (Sigma, USA), the rats were anaesthetised with a mixture of ketamine/xylazine and located in a stereotaxic frame (David Kopf Instruments, USA) with flat-skull position. Under sterilised conditions and anaesthesia, 21-gauge guide cannulae were implanted in the right and left lateral ventricles in the rats' brains. The stereotaxic coordinates were $-0.8 \mathrm{~mm}$ posterior; $\pm 1.5 \mathrm{~mm}$ lateral to the bregma; $-4.2 \mathrm{~mm}$ deep from the dural surface [52]. Cannulas were secured to the skull with acrylic dental cement. Afterward, stainless steel stylets (27 gauge) were inserted into the guide cannulae to keep patency prior to microinfusions. After surgery, animals were allowed to recover for at least seven days [48].
Injected ICV solution was STZ in all groups (except the control group), where $5 \mu \mathrm{l}$ /injection site was slowly injected by a 27-gauge Hamilton microsyringe $(10 \mu \mathrm{l})$ during a one-minute period. To ensure diffusion, the microsyringe was left in place for one minute after each infusion. Rats received STZ (3 $\mathrm{mg} / \mathrm{kg}$ in normal saline) on days 1 and 3 of the experiment [62].

\section{Experimental protocol}

One week after surgery, rats were trained using passive avoidance task. Then, the rats received ICV injections of STZ, and eight days after the first STZ injection, learning and memory impairment was tested using passive avoidance task. The rats that showed no learning and memory deficits after STZ-injection were excluded from the study. Six adult male rats were assigned to the control group - without cannula surgery, no drug treatment, and no behavioural test. Twenty-four rats, including STZ-injected rats, were then distributed in 4 groups (6 rats each), according to the treatment agent used; the untreated group (received vehicle: saline, $200 \mu \mathrm{l}$, IP injection) and hCG treated groups received hCG (Darou Pakhsh Pharmaceutical Mfg. Co., Iran) with three doses of 50, 100, and $200 \mathrm{IU} / 200 \mu \mathrm{l}$ saline for three days, respectively. The IP injections of hCG and or saline were given at 9:00 a.m. On the last injection day, the memory investigations were carried out 6 hours later at 3:00 p.m. [45]. Doses of hCG were selected based on a previous study [45].

\section{Passive avoidance task}

The passive avoidance task (step-through inhibitory) has been used to study learning and memory in response to a stressful stimulus. This apparatus contained two equal light and dark boxes $\left(20 \times 20 \times 30 \mathrm{~cm}^{3}\right)$, connected to each other with a guillotine door $\left(7 \times 9 \mathrm{~cm}^{2}\right)$. The floor of the dark compartment was made up of stainless steel bars ( $3 \mathrm{~mm}$ in diameter and $1 \mathrm{~cm}$ intervals). All rats were allowed to adapt in the experimental room for at least one hour prior to the experiments. Then, each rat was gently placed in the light compartment; the guillotine door was opened after $5 \mathrm{~s}$ and the rat was allowed to enter the dark compartment. The latency with which the rat entered the dark box was recorded (acquisition trial). Rats that had 
an initial latency of more than $120 \mathrm{~s}$ were excluded from further experiments. When the rat completely entered the dark compartment, the guillotine door was closed and an electric shock (1.5 mA intensity, $50 \mathrm{~Hz}$ ) was sent to the floor grids for $3 \mathrm{~s}$ and then after $20 \mathrm{~s}$, the rat was returned to its home cage. Two minutes later, the rat was retested in the similar way as in the previous trials; if the rat during $120 \mathrm{~s}$ did not enter the dark compartment, a successful acquisition of inhibitory avoidance response was recorded. Otherwise, when the rat entered the dark box before $120 \mathrm{~s}$, the guillotine door was closed and the rat received the shock again. After retesting, if the rat learned inhibitory avoidance response successfully, it was relocated to the cage. On the test day each rat was gradually placed in the light compartment for the retention trial and the latency time to enter the dark compartment was recorded and described as step-through latency. The retention trial was set a limit of $300 \mathrm{~s}$ as cut-off time [10].

\section{Tissue preparation}

Forty-eight hours after the last test, all rats were anaesthetised with chloroform, and the brains were rapidly detached and rinsed with ice-cold PBS solution $(\mathrm{pH}$ 7.4) to remove any blood clots. The hippocampal slices of one hemisphere were homogenised in a certain amount of PBS solution and then centrifuged at $5000 \mathrm{rpm}$ for 20 minutes. The supernatants were stored at $-20^{\circ} \mathrm{C}$ until used for phosphorylated tau protein assay by ELISA technique. The brain tissue of another hemisphere was removed and used for an indirect immunohistochemistry technique.

\section{Determination of phosphorylated tau protein concentration in hippocampus tissue by ELISA}

The phosphorylated tau protein concentration in the hippocampus was determined using an ELISA kit (ZellBio Gmbh, Germany) in hippocampus tissue. A kit was used based on the Biotin double antibody sandwich method. The colour change was measured with an ELISA reader at a wavelength of $450 \mathrm{~nm}$. The phosphorylated tau protein concentration of hippocampus tissue was expressed as nanograms per litre of tissue homogenised.

\section{Immunohistochemical staining}

The brain tissue of another hemisphere was fixed in $4 \%$ paraformaldehyde for one week. Histological processing including dehydration, clarification with xylene, and then embedding in paraffin wax was performed [34]. The 6- $\mu \mathrm{m}$ sagittal serial sections were collected from the hippocampal formation at the following coordinates: lateral $1.40 \mathrm{~mm}$ to $3.90 \mathrm{~mm}$ [52]. An interval of $24 \mu \mathrm{m}$ was placed between each two serial sections. Five slices from each hippocampus were selected for immunohistochemistry staining. Then immunohistochemical staining was carried out as described previously [48]. Briefly, sections after deparaffinisation with xylene, rehydration in graded alcohol solutions, and washing with distilled water, were incubated at $60^{\circ} \mathrm{C}$ for 5 minutes. Then the sections were covered with epitope retrieval solution (Tashkis Baft, Iran) at $90-95^{\circ} \mathrm{C}$ for 20 minutes, cooled at room temperature for 20 minutes, and washed with washing buffer (PBS/Tween 20 in $0.1 \%$ Triton $X$-100). Subsequently, the slides were placed in 3.5\% hydrogen peroxide, washing buffer, blocked with avidin/biotin blocking solution (Dako, Denmark) for 20 minutes at room temperature and again rinsed with washing buffer. Subsequently, samples were incubated at $4^{\circ} \mathrm{C}$ overnight with Anti-hCG Receptor Rabbit monoclonal antibody (1 : 200, Abcam Inc., USA) and washed with washing buffer, anti-rabbit IgG antibody (Abcam Inc., USA) was applied for 60 minutes at $37^{\circ} \mathrm{C}$, and then they were washed. Incubation with streptavidin HRP protein (1:5000, Abcam Inc., USA) for 30 minutes at room temperature and washing were the next processes. Chromogen DAB was used (Dako, Denmark), which was applied on the slices for 20 minutes at room temperature, followed by rinsing with distilled water. Meyer's Haematoxylin was used to stain the background by applying it lightly on the slides for 3-4 seconds. The sections were rinsed with distilled water. The slices were dehydrated, cleared, and finally mounted with Entellan (Merck, Germany) glue, which is suitable for visualisation under a light microscope.

\section{Immunohistochemical evaluation}

The stained hCG receptor-ir neurons were photographed by digital camera (DP72, Olympus, Japan) equipped with a (BX 51, Olympus, Japan) light microscope for hippocampal CA1 and CA3 areas and dental gyrus area. For CA1 and CA3 a field of 30,000 $\mathrm{m}^{2}$, 
and because of the density in the DG area a field of $4800 \mu^{2}$, was selected. Using Image J software the density of the hCG receptor-ir neurons was measured [48].

\section{Statistical analysis}

SPSS 16.0 (Armonk, NY, USA) for Windows for statistical data processing was used, and results were expressed as mean \pm SD. To examine the normal distribution, data was carried out by Shapiro-Wilk test. By one-way analysis of variance followed by post-hoc Tukey test, data were analysed for overall multiple comparisons. For all comparisons, $p<0.05$ was considered to be statistically significant.

\section{Results}

\section{Behavioural results}

As shown in Figure 1 (after STZ injection), treatment of the rats with STZ decreased the step-through latency time. In the other words, STZ impaired their inhibitory passive avoidance memory. On the final test day, hCG injection with doses of 50, 100, and $200 \mathrm{IU} / 200 \mu \mathrm{l}$ saline increased the step-through latency time compared to the STZ-saline group, confirming an increase in improvement of inhibitory passive avoidance memory. Tukey post-hoc analysis showed that there was a significant difference between $200 \mathrm{IU} / 200 \mu \mathrm{l}$ saline dose of hCG and the STZsaline groups' step-through latency time $(p<0.001$, Fig. 1). Furthermore, we observed significant differences in the step-through latency time among the hCG-treated groups $(p<0.01$, Fig. 1). These results demonstrated that hCG inhibited the effects of STZ treatment.

\section{The phosphorylated tau concentration in the hippocampus}

We observed a significant increase in the phosphorylated tau concentration of the hippocampus in treated rats with STZ in comparison to the control group ( $p<0.001$, Fig. 2). The phosphorylated tau concentration decreased slightly after treatment with hCG at 50 and $100 \mathrm{lU} / 200 \mu \mathrm{l}$ saline doses (Fig. 2). Significantly, the phosphorylated tau concentration in the hippocampus was lower in the hCG group (200 IU/200 $\mu \mathrm{l}$ saline) than in the STZ-saline group $(p<0.001$, Fig. 2), but we did not see differences in the phosphorylated tau concentration among the hCG-treated groups (Fig. 2).

\section{Hippocampal hCG receptor-ir neuron density}

In CA1, CA3, and DG hippocampal areas after treatment with STZ, the number of hCG receptor-ir neurons

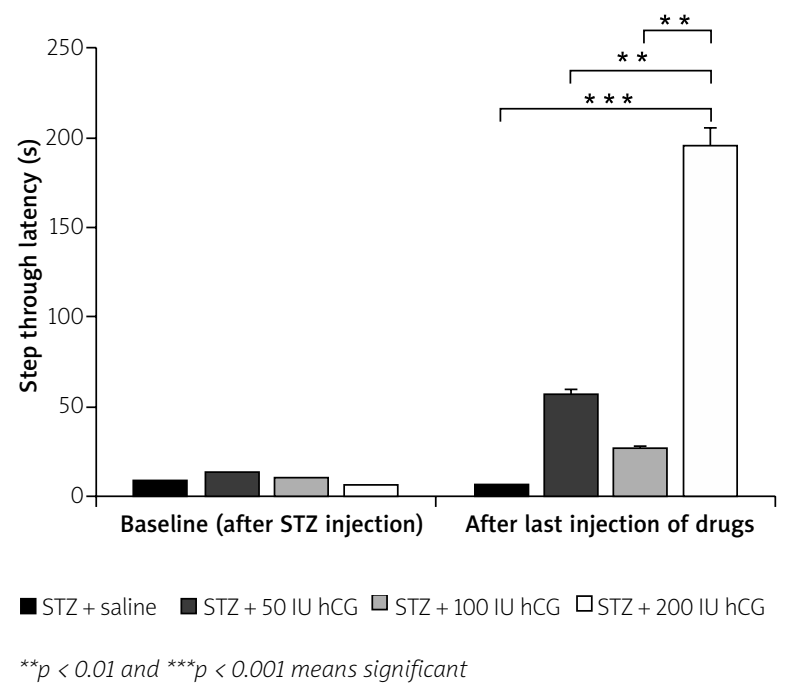

Fig. 1. The step-through latency time after treatment with human chorionic gonadotropin (hCG). Columns represent mean \pm SD.

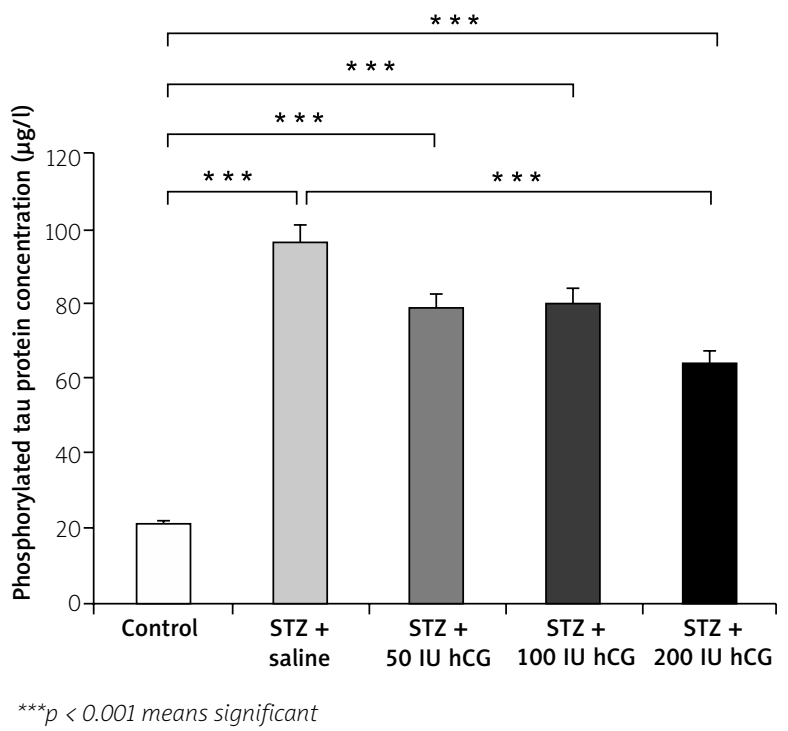

Fig. 2. Effect of human chorionic gonadotropin (hCG) on the phosphorylated tau protein concentration in the hippocampus. Columns represent mean \pm SD. 

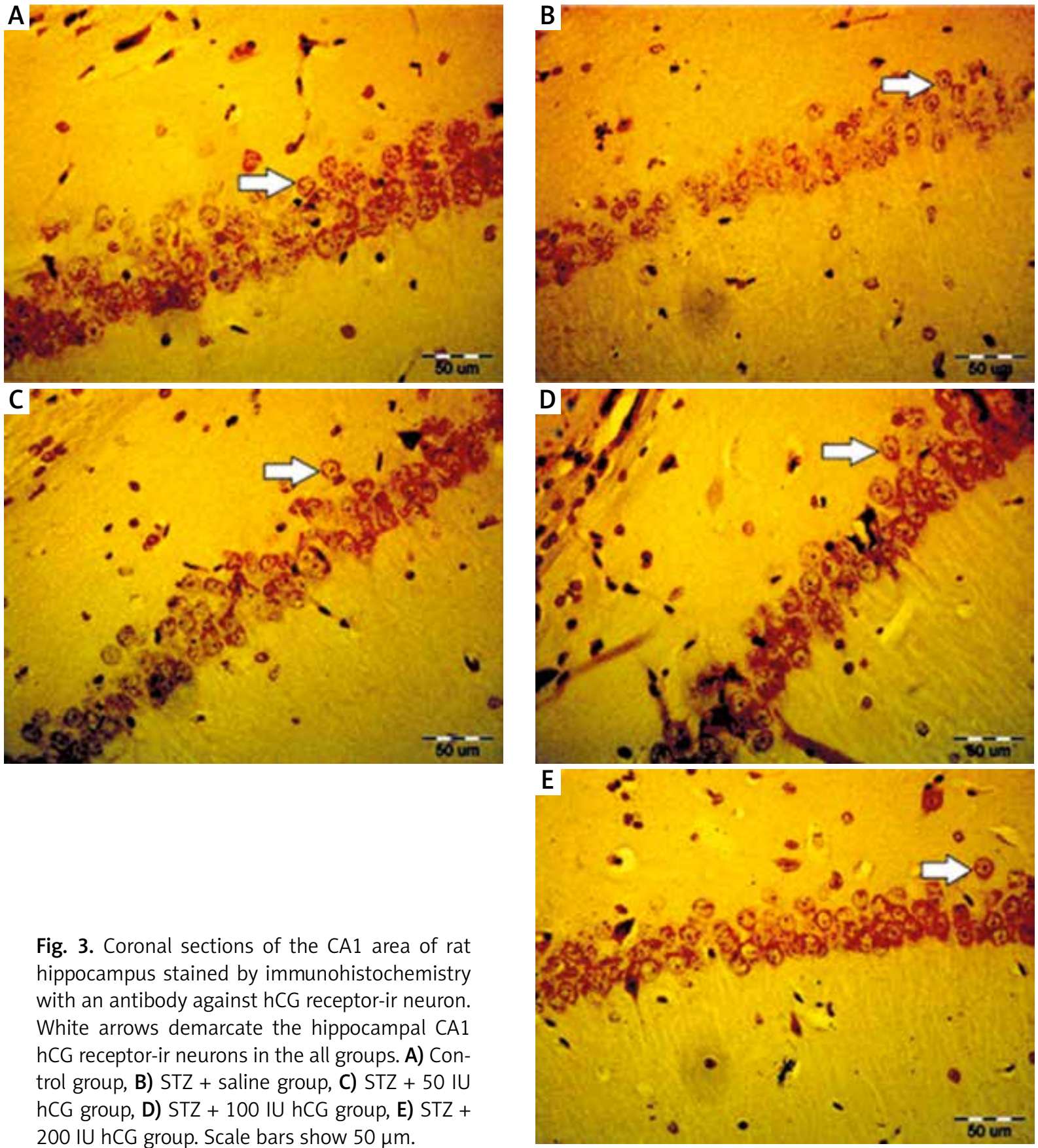

Fig. 3. Coronal sections of the CA1 area of rat hippocampus stained by immunohistochemistry with an antibody against hCG receptor-ir neuron. White arrows demarcate the hippocampal CA1 hCG receptor-ir neurons in the all groups. A) Control group, B) STZ + saline group, C) STZ + $50 \mathrm{IU}$ hCG group, D) STZ + 100 IU hCG group, E) STZ + 200 IU hCG group. Scale bars show $50 \mu \mathrm{m}$.

was decreased (Figs. 3 and 4). Furthermore, we observed a significant difference among control and STZ-saline groups in the DG area of the hippocampus $(p<0.05$, Fig. 4). After treatment with hCG, we observed an apparent rise in the number of hCG receptor-ir neurons at CA1 and CA3 of the hippocampus and DG area (Figs. 3 and 4). Our results also showed a significant increase of the hCG receptor-ir neuron numbers in hCG-treated

rats with 50,100 , and $200 \mathrm{IU} / 200 \mu \mathrm{l}$ saline doses at hippocampal CA1 and DG areas (Fig. 4). In the CA3 area of the hippocampus the density of hCG receptor-ir neurons was significantly higher in the hCG group (dose of $200 \mathrm{IU} / 200 \mu \mathrm{l}$ saline) than in the STZ-saline group ( $p<0.05$, Fig. 4 ). In the DG area of the hippocampus, we observed significant differences among hCG-treated rats with different doses of hCG (Fig. 4). 


\section{Discussion}

We showed that a dose of $200 \mathrm{IU} / 200 \mu \mathrm{l}$ saline hCG can improve inhibitory passive avoidance memory deficiency and decrease hippocampal phosphorylated tau concentration in ICV-STZ injected rats. Furthermore, our data revealed that hCG at a high dose (200 IU/200 $\mu \mathrm{l}$ saline) increased the number of hCG receptor-ir neurons in the hippocampus of ICV-STZ injected rats.

Streptozotocin injection effects numerous AD-like behavioural and pathological signs, such as memory deficit, increased acetylcholinesterase activity, longterm potentiation, and reduced hippocampal synaptic transmission [1,2,57]. It also caused tau hyperphosphorylation in the brain [26]. As expected, in our study we found that the injection of STZ caused a passive avoidance memory deficit. This result of STZ-induced memory deficit is in agreement with Agrawal et al. (2011) [2] and Zamani et al. (2011) [64].

After treatment with a high dose of hCG, passive avoidance memory deficit induced by STZ was attenuated. Similarly, Babahajian et al. [12] demonstrated that co-administration of vitamin E and hCG improved ischaemia-induced neurodegeneration and passive avoidance memory impairment. In contrast with our findings, Lucaks et al. [45] showed that a single high dose of hCG administered to ovariectomised rats has no effect on latency to enter the open field or on working memory in the T-maze, while Berry et al. [14] found that single or multiple injections of high hCG doses to ovariectomised rats negated the benefits of oestrogen replacement on working memory in the object location test and reference memory in the Barnes maze. Also, Berry et al. [14] reported that hCG treatment to oestradiol-implanted female rats significantly increased soluble $A \beta 40$ and $A \beta 42$ levels. Furthermore, Barron et al. [13] reported that hCG administration induces hyperactivity and anxiety (in open field Maze and Taste Neophobia Task) and working memory dysfunction, without altering reference memory (in Morris Water Maze). In this study, they also found that although treatment with hCG slightly increased Ab40 levels, levels of the longer, more toxic form (Ab42) were unaffected. Burnham et al. [23] also found that females that received hCG in the dorsal hippocampus had reduced spatial memory compared to vehicle infusions, showing that $\mathrm{hCG} / \mathrm{LH}$ can act directly on the hippocampus to affect cognition in female rats. Also, they found

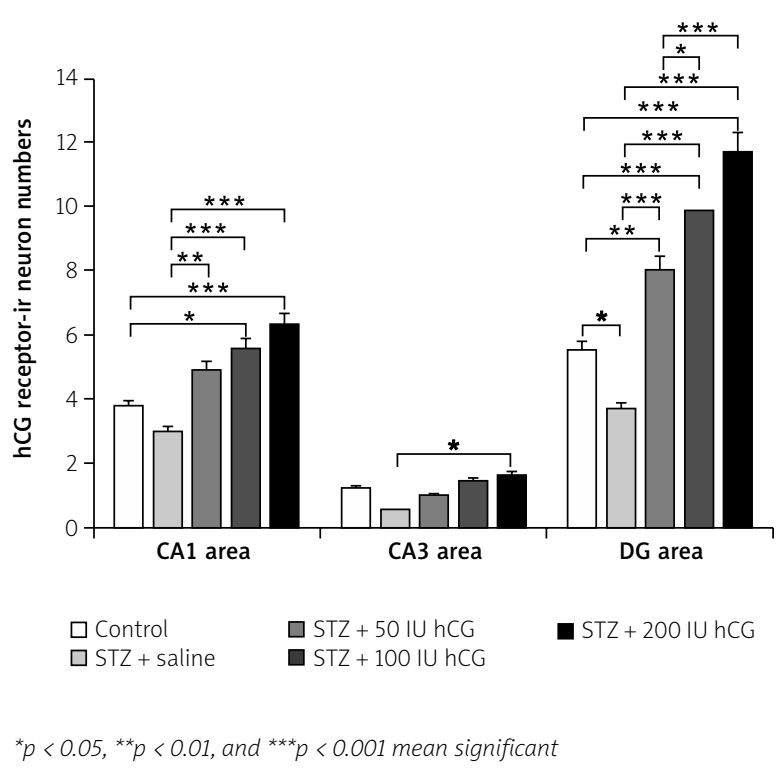

Fig. 4. The bar graphs represent the mean density of hCG receptor-ir neurons in control, STZ + saline, STZ + 50 IU hCG, STZ + 100 IU hCG, and $\mathrm{STZ}+200$ IU hCG groups in the hippocampal CA1, CA3, and DG areas. Columns represent mean $\pm \mathrm{SD}$.

that administration of the LH/CG receptor antagonist, deglycosylated $\mathrm{hCG}$, to the dorsal hippocampus of ovariectomised female rats reversed the deficit in spatial memory. Indeed, this shows that even when oestradiol levels are moderately high, hCG/LH can suppress spatial memory [14]. These studies implicate the gonadotropin hormones in complex and diverse actions in the brain and may have significance for understanding the effects of menopausal hormone changes on cognition and AD risk [13].

Abnormal hyperphosphorylated tau protein can cause NFTs in neuron cell bodies or in other cells of the brain $[8,20,22]$. In numerous neurodegenerative diseases known as "tauopathies", these types of intraneuronal tau masses are observed. Alzheimer's disease, frontotemporal dementia, progressive supranuclear palsy, Parkinson's disease, and Pick's disease are some of them $[20,22]$. In AD, the earliest histopathological alterations with the hallmarks of neurofibrillary masses and amyloid depositions are commonly identified within the medial temporal lobes, including the entorhinal cortex, the parahippocampus, the hippocampus, amygdala, and uncus, and spread throughout the frontal, parietal, and 
temporal neocortices and the subcortical regions by the time of a full diagnosis of AD [63].

We found that STZ increased the phosphorylated tau concentration in the hippocampus. Our data are similar with those reported by Deng et al. (2009) [29] and Correia et al. (2013) [27], showing that STZ injection raises the expression of hyperphosphorylated tau. In tau transgenic mice, hippocampal tauopathy led to hippocampus-dependent learning and memory ability deficiencies [60].

Herein, we observed a decrease in phosphorylated tau concentration in high dose of hCG-treated rats. This result shows that hCG effectually protect the neurons against phosphorylated tau, which could explain the effect of hCG in reversing memory deficits. Most studies endorse a link between phosphorylation of tau and $A D$ behavioural signs and suggest that decreasing tau phosphorylation may reduce cognitive deficits [41].

In the present study, STZ reduced the number of hCG receptor-ir neurons in all subareas of hippocampus and hCG therapy could increase these neurons in the hippocampus. Interestingly, LH receptor expression in glial cells increases with glial proliferation [4], and in primary neuronal cultures, activation of $\mathrm{LH}$ receptor with hCG increases the number of neurite-bearing cells [3]. Furthermore, cell viability was increased with treatment by hCG, as observed through increased total protein content and decreased DNA fragmentation [3]. The findings of Babahajian et al. indicated that the application of Trolox and hCG at the same time after ischaemia-reperfusion had a neuroprotective effect and improved the neuronal cell survival [11].

Because hCG and LH are similar structurally and functionally [47], LH has been shown to regulate phosphorylation of tau in vitro [24] and in vivo [40]. Genetic ablation of $\mathrm{LH}$ receptor in a bigenic mouse model of AD (APPsw ${ }^{+}$mice) reduced tau phosphorylation (by $\sim 50 \%$ ) that was induced by $A \beta$ precursor protein overexpression in these animals [40]. Luteinising hormone has been revealed to modulate the expression of many genes involved in cytoskeletal organisation [56]. In this respect, it has reported concurrent rises in both LH expression [43] and phosphorylation of tau $[31,42]$ by rat embryonic neurons during in vitro differentiation. Importantly, Palm et al. reported that the levels of LH mRNA are reduced in hippocampal formation of $A D$ patients compared to controls, and in ovariectomized $3 \times$ Tg AD mice LH immunoreactivity in the superior colliculus was reduced [51].

\section{Conclusions}

In conclusion, hCG can provide effective protection against memory deficits induced by STZ, and it can inhibit accumulation of tau hyperphosphorylation in all areas of the hippocampus. Furthermore, hCG can increase the hCG receptor-ir neuron numbers in the rats hippocampus after injection of STZ.

\section{Acknowledgments}

This article was derived from a thesis by (Gozal Bahlakeh) as a part of Master's degree in the field of Anatomical Sciences at Gorgan school of Medicine/Neuroscience Behavioural Research Centre of Golestan University of Medical Sciences, Gorgan, Iran. With thanks to the Neuroscience Research Center for Behavioural and Histological Experiments and thanks for the financial support of the Deputy of Research and Technology of Golestan University of Medical Sciences.

\section{Conflicts of interest}

The authors report no conflicts of interest.

\section{References}

1. Agrawal R, Tyagi E, Shukla R, Nath C. A study of brain insulin receptors, AChE activity and oxidative stress in rat model of ICV STZ induced dementia. Neuropharmacology 2009; 56: 779-787.

2. Agrawal R, Tyagi E, Shukla R, Nath C. Insulin receptor signaling in rat hippocampus: a study in STZ (ICV) induced memory deficit model. Eur Neuropsychopharm 2011; 21: 261-273.

3. Al-Hader AA, Lei ZM, Rao CV. Neurons from fetal rat brains contain functional luteinizing hormone/chorionic gonadotropin receptors. Biol Reprod 1997; 56: 1071-1076.

4. Al-Hader AA, Lei ZM, Rao CV. Novel expression of functional luteinizing hormone/chorionic gonadotropin receptors in cultured glial cells from neonatal rat brains. Biol Reprod 1997; 56 : 501-507.

5. Anastasio TJ. Data-driven modeling of Alzheimer Disease pathogenesis. J Theor Biol 2011; 290: 60-72.

6. Alzheimer's Association. 2014 Alzheimer's disease facts and figures. Alzheimers Dement 2014; 10: e47-e92.

7. Alzheimer's Association. 2016 Alzheimer's disease facts and figures. Alzheimers Dement 2016; 12: 459-509.

8. Avila J. Tau phosphorylation and aggregation in Alzheimer's disease pathology. FEBS Lett 2006; 580: 2922-2927.

9. Avila J, Lucas JJ, Perez M, Hernandez F. Role of tau protein in both physiological and pathological conditions. Physiol Rev 2004; 84: 361-384. 
10. Azami NS, Piri M, Oryan S, Jahanshahi M, Babapour V, Zarrindast MR. Involvement of dorsal hippocampal $\alpha$-adrenergic receptors in the effect of scopolamine on memory retrieval in inhibitory avoidance task. Neurobiol Learn Mem 2010; 93: 455-462.

11. Babahajian A, Fotovat N, Soleimani M. P17: HCG and Trolox Reduced the Apoptotic Hippocampus Neuronal Cells in Ischemia Reperfusion Mice Model. Shefaye Khatam 2015; 2: 67.

12. Babahajian A, Rasouli H, Katebi M, Sarveazad A, Soleimani M, Nobakht M. Effect of human chorionic gonadotropin and vitamine $E$ on cellular density of CA1 hippocampal area, learning ability and memory, following ischemia-reperfusion injury in mice. J Gorgan Uni Med Sci 2014; 15: Pe23-Pe27.

13. Barron AM, Verdile G, Taddei K, Bates KA, Martins RN. Effect of Chronic hCG administration on Alzheimer's-related cognition and $A \beta$ accumulation in PS1KI mice. Endocrinology 2010; 151 5380-5388.

14. Berry A, Tomidokoro Y, Ghiso J, Thornton J. Human chorionic gonadotropin (a luteinizing hormone homologue) decreases spatial memory and increases brain amyloid- $\beta$ levels in female rats. Horm Behav 2008; 54: 143-152.

15. Bowen RL, Isley JP, Atkinson RL. An association of elevated serum gonadotropin concentrations and Alzheimer disease? J Neuroendocrinol 2000; 12: 351-354.

16. Bowen RL, Smith MA, Harris PL, Kubat Z, Martins RN, Castellani RJ, Perry G, Atwood CS. Elevated luteinizing hormone expression colocalizes with neurons vulnerable to Alzheimer's disease pathology. J Neurosci Res 2002; 70: 514-518.

17. Bowen RL, Verdile G, Liu T, Parlow AF, Perry G, Smith MA, Martins RN, Atwood CS. Luteinizing hormone, a reproductive reg ulator that modulates the processing of amyloid- $\beta$ precursor protein and amyloid- $\beta$ deposition. J Biol Chem 2004; 279 : 20539-20545.

18. Braak H, Braak E. Staging of Alzheimer's disease-related neurofibrillary changes. Neurobiol Aging 1995; 16: 271-278.

19. Brett $M$, Baxendale S. Motherhood and memory: a review. Psychoneuroendocrinology 2001; 26: 339-362.

20. Brunden KR, Ballatore C, Crowe A, Smith AB, Lee VM-Y, Trojanowski JQ. Tau-directed drug discovery for Alzheimer's disease and related tauopathies: a focus on tau assembly inhibitors. Exp Neurol 2010; 223: 304-310.

21. Bukovsky A, Indrapichate K, Fujiwara H, Cekanova M, Ayala ME, Dominguez R, Caudle MR, Wimalsena J, Elder RF, Copas P, Fos ter JS, Fernando RI, Henley DC, Upadhyaya NB. Multiple luteinizing hormone receptor (LHR) protein variants, interspecies reactivity of anti-LHR mAb clone 3B5, subcellular localization of LHR in human placenta, pelvic floor and brain, and possible role for LHR in the development of abnormal pregnancy, pelvic floor disorders and Alzheimer's disease. Reprod Biol Endocrinol 2003; 1: 46.

22. Bulic B, Pickhardt M, Mandelkow EM, Mandelkow E. Tau protein and tau aggregation inhibitors. Neuropharmacology 2010; 59: 276-289.

23. Burnham V, Sundby C, Laman-Maharg A, Thornton J. Luteinizing hormone acts at the hippocampus to dampen spatial memory. Horm Behav 2017; 89: 55-63.
24. Casadesus G, Webber KM, Atwood CS, Bowen RL, Perry G, Smith MA. P3-296: Luteinizing hormone mediates Alzheimer-type changes in neurons. Alzheimers Dement 2006; 2 Suppl: S462.

25. Casadesus G, Webber KM, Atwood CS, Pappolla MA, Perry G, Bowen RL, Smith MA. Luteinizing hormone modulates cognition and amyloid- $\beta$ deposition in Alzheimer APP transgenic mice. BBA-Mol Basis Dis 2006; 1762: 447-452.

26. Chen Y, Liang Z, Blanchard J, Dai CL, Sun S, Lee MH, GrundkeIqbal I, Iqbal K, Liu F, Gong CX. A non-transgenic mouse model (icv-STZ mouse) of Alzheimer's disease: similarities to and differences from the transgenic model (3xTg-AD mouse). Mol Neurobiol 2013; 47: 711-725.

27. Correia SC, Santos RX, Santos MS, Casadesus G, Lamanna JC, Perry G, Smith MA, Moreira PI. Mitochondrial abnormalities in a streptozotocin-induced rat model of sporadic Alzheimer's disease. Curr Alzheimer Res 2013; 10: 406-419.

28. Delacourte A, David JP, Sergeant N, Buee L, Wattez A, Vermersch P, Ghozali F, Fallet-Bianco C, Pasquier F, Lebert F, Petit H, Di Menza C. The biochemical pathway of neurofibrillary degeneration in aging and Alzheimer's disease. Neurology 1999; 52: 1158-1165.

29. Deng Y, Li B, Liu Y, Iqbal K, Grundke-lqbal I, Gong CX. Dysregulation of insulin signaling, glucose transporters, O-GlcNAcylation, and phosphorylation of tau and neurofilaments in the brain: Implication for Alzheimer's disease. Am J Pathol 2009; 175: 2089-2098.

30. Duyckaerts C, Hauw JJ. Diagnosis and staging of Alzheimer disease. Neurobiol Aging 1997; 18 (4 Suppl): S33-S42.

31. Goedert M, Jakes R, Crowther RA, Six J, Lübke U, Vandermeeren $M$, Cras P, Trojanowski JQ, Lee VM. The abnormal phosphorylation of tau protein at Ser-202 in Alzheimer disease recapitulates phosphorylation during development. Proc Natl Acad Sci U S A 1993; 90: 5066-5070.

32. Grober E, Dickson D, Sliwinski MJ, Buschke H, Katz M, Crystal H, Lipton RB. Memory and mental status correlates of modified Braak staging. Neurobiol Aging 1999; 20: 573-579.

33. Hebert LE, Weuve J, Scherr PA, Evans DA. Alzheimer disease in the United States (2010-2050) estimated using the 2010 census. Neurology 2013; 80: 1778-1783.

34. Jahanshahi M, Nickmahzar E, Babakordi F. The effect of Ginkgo biloba extract on scopolamine-induced apoptosis in the hippocampus of rats. Anat Sci Int 2013; 88: 217-222.

35. Johnson GV, Stoothoff WH. Tau phosphorylation in neuronal cell function and dysfunction. J Cell Sci 2004; 117: 5721-5729.

36. Kolarova M, García-Sierra F, Bartos A, Ricny J, Ripova D. Structure and pathology of tau protein in Alzheimer disease. Int J Alzheimer Dis 2012; 2012: 731526.

37. Le Freche H, Brouillette J, Fernandez-Gomez FJ, Patin P, Caillierez R, Zommer N, Sergeant N, Buée-Scherrer V, Lebuffe G, Blum D, Buée L Tau phosphorylation and sevoflurane anesthesia: an association to postoperative cognitive impairment. Anesthesiology 2012; 116: 779-787.

38. Lei ZM, Rao CV. Neural actions of luteinizing hormone and human chorionic gonadotropin. Semin Reprod Med 2001; 19: 103-109.

39. Lei ZM, Rao CV, Kornyei JL, Licht P, Hiatt ES. Novel expression of human chorionic gonadotropin/luteinizing hormone receptor gene in brain. Endocrinology 1993; 132: 2262-2270.

40. Lin J, Li X, Yuan F, Lin L, Cook CL, Rao ChV, Lei Z. Genetic ablation of luteinizing hormone receptor improves the amyloid pathol- 
ogy in a mouse model of Alzheimer disease. J Neuropathol Exp Neurol 2010; 69: 253-261.

41. Liu P, Zou LB, Wang LH, Jiao Q, Chi TY, Ji XF, Jin G. Xanthoceraside attenuates tau hyperphosphorylation and cognitive deficits in intracerebroventricular-streptozotocin injected rats. Psychopharmacology 2014; 231: 345-356.

42. Liu T, Perry G, Chan - HW, Verdile G, Martins RN, Smith MA, Atwood CS. Amyloid- $\beta$-induced toxicity of primary neurons is dependent upon differentiation-associated increases in tau and cyclin-dependent kinase 5 expression. J Neurochem 2004; 88: 554-563.

43. Liu T, Wimalasena J, Bowen RL, Atwood CS. Luteinizing hormone receptor mediates neuronal pregnenolone production via up regulation of steroidogenic acute regulatory protein expression. J Neurochem 2007; 100: 1329-1339.

44. Lukács H. Rat as model for studying behavior effects of hCG. Semin Reprod Med 2001; 19: 111-119.

45. Lukacs H, Hiatt ES, Lei ZM, Rao CV. Peripheral and intracerebroventricular administration of human chorionic gonadotropin alters several hippocampus-associated behaviors in cycling female rats. Horm Behav 1995; 29: 42-58.

46. McFarland KC, Sprengel R, Phillips HS, Köhler M, Rosemblit N, Nikolics K, Segaloff DL, Seeburg PH. Lutropin-choriogonadotropin receptor: unusual member of the g protein-coupled receptor family. Science 1989; 245: 494-499.

47. Meng XL, Rennert OM, Chan WY. Human chorionic gonadotropin induces neuronal differentiation of PC12 cells through activation of stably expressed lutropin/choriogonadotropin receptor. Endocrinology 2007; 148: 5865-5873.

48. Moghadami S, Jahanshahi M, Sepehri H, Amini H. Gonadectomy reduces the density of androgen receptor-immunoreactive neurons in male rat's hippocampus: testosterone replacement compensates it. Behav Brain Funct 2016; 12: 5.

49. Niikura T, Hashimoto Y, Tajima H, Nishimoto I. Death and survival of neuronal cells exposed to Alzheimer's insults. J Neurosci Res 2002; 70: 380-391.

50. Obulesu M, Lakshmi MJ. Apoptosis in Alzheimer's disease: an understanding of the physiology, pathology and therapeutic avenues. Neurochem Res 2014; 39: 2301-2312.

51. Palm R, Chang J, Blair J, Garcia-Mesa Y, Lee HG, Castellani RJ, Smith MA, Zhu X, Casadesus G. Down-regulation of serum gonadotropins but not estrogen replacement improves cognition in aged-ovariectomized 3xTg AD female mice. J Neurochem 2014; 130: 115-125.

52. Paxinos G, Watson C. The rat brain in stereotaxic coordinates. Academic Press, San Diego 2007.

53. Rahman NA, Rao CV. Recent progress in luteinizing hormone/ human chorionic gonadotrophin hormone research. Mol Hum Reprod 2009; 15: 703-711.

54. Rao C. Involvement of Luteinizing Hormone in Alzheimer Disease Development in Elderly Women. Reprod Sci 2016; 24: $355-$ 368.

55. Rofe Y, Littner MB, Lewin I. Emotional experiences during the three trimesters of pregnancy. J Clin Psychol 1993; 49: 3-12.

56. Sasson R, Rimon E, Dantes A, Cohen T, Shinder V, Land-Bracha A, Amsterdam A. Gonadotrophin-induced gene regulation in human granulosa cells obtained from IVF patients. Modulation of steroidogenic genes, cytoskeletal genes and genes coding for apoptotic signalling and protein kinases. Mol Hum Reprod 2004; 10: 299-311.

57. Shonesy BC, Thiruchelvam K, Parameshwaran K, Rahman EA, Karuppagounder SS, Huggins KW, Pinkert CA, Amin R, Dhanasekaran M, Suppiramaniam V. Central insulin resistance and synaptic dysfunction in intracerebroventricular-streptozotocin injected rodents. Neurobiol Aging 2012; 33: 430. e435-430.

58. Short RA, O'Brien PC, Graff-Radford NR, Bowen RL. Elevated gonadotropin levels in patients with Alzheimer disease. Proc Mayo Clin Proc 2001; 76: 906-909.

59. Toth P, Lukacs H, Hiatt ES, Reid KH, lyer V, Rao CV. Administration of human chorionic gonadotropin affects sleep-wake phases and other associated behaviors in cycling female rats. Brain Res 1994; 654: 181-190.

60. Van der Jeugd A, Ahmed T, Burnouf S, Belarbi K, Hamdame M, Grosjean ME, Humez S, Balschun D, Blum D, Buée L, D’Hooge R. Hippocampal tauopathy in tau transgenic mice coincides with impaired hippocampus-dependent learning and memory, and attenuated late-phase long-term depression of synaptic transmission. Neurobiol Learn Mem 2011; 95: 296-304.

61. Webber KM, Casadesus G, Atwood CS, Bowen RL, Perry G, Smith MA. Gonadotropins: a cohesive gender-based etiology of Alzheimer disease. Mol Cell Endocrinol 2007; 260: 271-275.

62. Weerateerangkull P, Praputpittaya C, Banjerdpongchai R. Effects of ascorbic acid on streptozotocin-induced oxidative stress and memory impairment in rats. Thai J Physiological Sci 2008; 20: 54-61.

63. Yang J, Pan P, Song W, Huang R, Li J, Chen K, Gong Q, Zhong J, Shi $\mathrm{H}$, Shang $\mathrm{H}$. Voxelwise meta-analysis of gray matter anomalies in Alzheimer's disease and mild cognitive impairment using anatomic likelihood estimation. J Neurol Sci 2012; 316: 21-29.

64. Zamani Z, Reisi P, Alaei H, Pilehvarian A, Zamani Z. Effect of Royal Jelly (RJ) on Learning and Memory in Rats after Intracerebroventricular Injection of Streptozotocin (icv-STZ). J Isfahan Med Sch 2011; 28: 1825-1834.

65. Zhang W, Lei Z, Rao CV. Immortalized hippocampal cells contain functional luteinizing hormone/human chorionic gonadotropin receptors. Life Sci 1999; 65: 2083-2098.

66. Zhang Z, Simpkins JW. Okadaic acid induces tau phosphorylation in SH-SY5Y cells in an estrogen-preventable manner. Brain Res 2010; 1345: 176-181. 